\title{
In vitro evaluation of ivermectin, moxidectin, albendazole and pyrantel against cyathostomins of horses
}

Avaliação in vitro da ivermectina, moxidectina, albendazole e pirantel contra ciatostomíneos de equinos

\author{
Marcelo Beltrão Molento ${ }^{1,2 *}$; Ricardo José Canever ${ }^{1}$
}

\begin{abstract}
${ }^{1}$ Laboratório de Doenças Parasitárias, Departamento de Medicina Veterinária, Universidade Federal do Paraná - UFPR, Curitiba, PR, Brasil
${ }^{2}$ Instituto Nacional de Ciência e Tecnologia Genético-Sanitária da Pecuária Brasileira - INCT-Pecuária, Belo Horizonte, MG, Brasil
\end{abstract}

Received May 31, 2017

Accepted August 30, 2017

\begin{abstract}
Cyathostomins are the most prevalent nematodes of horses, and multidrug resistance has been reported worldwide. There is a need to implement alternative drug monitoring analytical tests. The objective of this study was to determine the consistency (5 repetitions) of the larval migration on agar test (LMAT) using ivermectin, moxidectin, pyrantel or albendazole against cyathostomin infective-stage larvae in eight different concentrations. LMAT showed a strong coefficient of determination $\left(R^{2}>0.91\right)$, between the test repetitions $(n=5)$. The average $50 \%$ effective concentration (EC50) for ivermectin, moxidectin, pyrantel and albendazole were $0.0404,0.0558,0.0864$ and $0.0988 \mathrm{nMol}$, respectively. The results of the EC50 for albendazole showed the greatest range of concentration. Ivermectin and moxidectin had the lowest in between-test variation. In the future, internationally certified susceptible isolates could be used for screening new drug candidates, or to follow up the pattern of drug efficacy from field populations.
\end{abstract}

Keywords: Horse, Anthelmintics, In vitro test, parasites.

\section{Resumo}

Ciatostomíneos são os nematodas mais prevalentes em equinos e a resistência múltipla foi relatada em todo o mundo. Existe a necessidade de implementar o monitoramento dos produtos com testes analíticos alternativos. O objetivo deste estudo foi determinar a consistência (5 repetiçôes) do teste de migração larval em ágar (TMLA) usando ivermectina, moxidectina, pirantel e albendazole contra larvas infectantes de ciatostomíneos em oito concentraçôes diferentes. O TMLA demonstrou um coeficiente de determinação $\left(R^{2}\right)$ acima de 0,91 entre as repetições do teste. A concentração efetiva para 50\% (CE50) para ivermectina, moxidectina, pirantel e albendazole foi de 0,0404; 0,0558; 0,0864 e 0,0988 nMol, respectivamente. A CE50 do albendazole demonstrou a maior amplitude entre os testes. A ivermectina e a moxidectina tiveram as menores variaçóes das doses entre as repetiçóes. No futuro, isolados certificados susceptíveis poderão ser testados com o TMLA para indicação de novos produtos e mesmo para acompanhar o perfil de eficácia de populaçóes do campo.

Palavras-chave: Cavalos, anti-helmínticos, teste in vitro, parasitos.

Cyathostomins, are the most prevalent helminth pathogens of horses (PEREGRINE et al., 2014). The attention toward these parasites has increased over the past decade, following the intense and efficient control of large strongyles with anthelmintic compounds. Although anthelmintic resistance has been broadly disseminated, it was restricted to phenothiazine, benzimidazoles (BZs) and pyrantel (PYR) (WIRTHERLE et al., 2004). The macrocyclic lactones, ivermectin (IVM) and moxidectin (MOX), are highly effective against cyathostomins, however, a number of reports have described cases of cyathostomin resistance to both compounds (MOLENTO et al., 2008; TRAVERSA et al., 2009; CANEVER et al., 2013).

*Corresponding author: Marcelo Beltráo Molento. Universidade Federal do Paraná - UFPR, Rua dos Funcionários, 1540, CEP 80035-050, Curitiba, PR, Brasil. e-mail: molento@ufpr.br
Nielsen et al. (2006) stated that it is essential to monitor any sustainable parasite control program, but the only practical test under field conditions is the fecal egg count reduction test (FECRT). It has now been two decades since the start of consistent use of in vitro tests as an alternative to the FECRT, and as a screening step in the search for new compounds (OLIVEIRA et al., 2017). The in vitro egg hatch test (EHT), larval development test (LDT) and the larval migration test (LMT) are tools that can also aid the diagnosis of resistance, and to screen for alternative medicines (KOTZE et al., 2006; PEACHEY et al., 2016; LÉGARÉ \& OUELLETTE, 2017). Although the tests have some particularities, they have been largely used in ruminant nematodes, particularly sheep (GILL et al., 1995; VÁRADY \& CORBA, 1999; MOLENTO \& PRICHARD, 2001) and cattle (DEMELER et al., 2010). A few studies have used these in vitro methods for horses (CRAVEN et al., 1999; 
KÖNIGOVÁ et al., 2003; LIND et al., 2005; PEACHEY et al., 2016). Craven et al. (1999) reported a comparison between the FECRT and EHT for detecting anthelmintic resistance in strongyles. Resistance to BZD was demonstrated in 33 out of 42 farms (79\%), when using FECRT, and in 32 out of 52 farms (62\%), when using the EHT. The larval migration on agar test (LMAT) is a variation of the LMT, and allows the observation of ruminant nematode larvae that pass through a mesh and an agar gel layer, which serve as a barrier (MOLENTO \& PRICHARD, 2001). Thus, with the advancement of cyathostomin multidrug resistance, the standardization of another in vitro test may become an important aid to drug monitoring. The objective of this study was to determine the consistency of the LMAT using four anthelmintic drugs against cyathostomins.

Third-stage infective larvae (L3) were obtained from fecal cultures that contained $96-100 \%$ cyathostomins (2-4\% of large strongyles). The compounds albendazole (ABZ), PYR, IVM and MOX were diluted to eight different concentrations (Table 1) and tested in five repetitions, under the same conditions. A control without any compound was included. The concentrations (in triplicates) were prepared by dissolving each drug concentrations in distilled water and DMSO (3\%). Fresh larvae (30 days old) were exsheathed with $0.3 \%$ sodium hypochlorite for $30 \mathrm{~min}$ before the test (MOLENTO \& PRICHARD, 2001). A total of 400 larvae were placed in the compound solution in 24-well plates at a volume of $1 \mathrm{ml} /$ well. For the first incubation period, the plates were incubated at $28^{\circ} \mathrm{C}$ for $6 \mathrm{~h}$. The second incubation began with the addition of $1 \mathrm{ml}$ of $1.4 \%$ agar into the solution. This 2-ml solution was then transferred into a previously prepared individual apparatus (MOLENTO \& PRICHARD, 2001) at $28{ }^{\circ} \mathrm{C}$ for $18 \mathrm{~h}$. During this period, the larvae were exposed to a $150 \mathrm{~W}$ light bulb to stimulate L3 migration. At the end, the

Table 1. Drug concentrations ( $\mathrm{nMol} / \mathrm{ml}, \log ^{-1}$ ) for albendazole, pyrantel, ivermectin and moxidectin used for the larval migration on agar test against cyathostomins of horses.

\begin{tabular}{cccc}
\hline Albendazole & Pyrantel & Ivermectin & Moxidectin \\
\hline $1,0 \mathrm{e}-010$ & $1,0 \mathrm{e}-010$ & $1,0 \mathrm{e}-010$ & $1,0 \mathrm{e}-010$ \\
$3,12 \mathrm{e}-009$ & $3,5 \mathrm{e}-009$ & $5,0 \mathrm{e}-010$ & $5,0 \mathrm{e}-010$ \\
$6,25 \mathrm{e}-009$ & $7,0 \mathrm{e}-009$ & $1,0 \mathrm{e}-009$ & $1,0 \mathrm{e}-009$ \\
$1,25 \mathrm{e}-008$ & $1,4 \mathrm{e}-008$ & $2,0 \mathrm{e}-009$ & $2,0 \mathrm{e}-009$ \\
$2,5 \mathrm{e}-008$ & $2,8 \mathrm{e}-008$ & $4,0 \mathrm{e}-009$ & $4,0 \mathrm{e}-009$ \\
$5,0 \mathrm{e}-008$ & $5,6 \mathrm{e}-008$ & $8,0 \mathrm{e}-009$ & $8,0 \mathrm{e}-009$ \\
$1,0 \mathrm{e}-007$ & $1,12 \mathrm{e}-007$ & $1,6 \mathrm{e}-008$ & $1,6 \mathrm{e}-008$ \\
$2,0 \mathrm{e}-007$ & $2,24 \mathrm{e}-007$ & $3,2 \mathrm{e}-008$ & $3,2 \mathrm{e}-008$ \\
\hline
\end{tabular}

solution was transferred to 50 - $\mathrm{ml}$ tubes which were centrifuged, then the supernatant was removed. The L3 solution $(150 \mu \mathrm{l})$ was examined under a microscope $(20 \mathrm{x})$ to count the number of migrating L3. Data $\left(X=\log ^{X}\right)$ were analyzed to obtain the $50 \%$ effective concentration (EC50) values, 95\% confidence interval and the coefficient of determination $\left(\mathrm{R}^{2}\right)$. The dose-response curves were generated using non-linear fit of the normalized transformed data using the PRISM 5 software.

Figure 1 shows the dose-response curves after the LMAT. The EC50 and $\mathrm{R}^{2}$ values for the five tests are presented in Table 2. The results of the EC50 for ABZ had the greatest range of concentration $[1.49(\log -7.69)$ to $20(\log -8.66) \mathrm{nMol}]$ between the tests. The EC50 value of PYR varied from 2.44 to $11.44 \mathrm{nMol}$, and all tests had a $\mathrm{R}^{2}$ above 0.94 . The tests with IVM and MOX showed the lowest variation in EC50 values between the tests, with an average $\mathrm{R}^{2}$ of 0.95 for IVM and 0.91 for MOX.

Attempts to develop and regularly use in vitro assays for the diagnosis of anthelmintic resistance in equine nematodes has shown limited success (VAN DOORN et al., 2010). The data obtained from the current study show that low concentrations of IVM and MOX were sufficient to inhibit the migration of $50 \%$ of L3, with little variability between the samples.

The results obtained for ABZ showed a wide variation (+/-0.156), and it was not possible to determine a safe cut-off value to the EC50. Considering the purpose of the LMAT, and the way in which inhibition of L3 migration occurs, we suggest that the LMAT is a good tool for detecting variation to IVM and MOX, but not so much for the BZs (ROTHWELL \& SANGSTER, 1993) as they share a similar mode of action (blocking calcium channel in the nervous cell). In the present study, the ABZ results did not show consistency, and even at very high concentrations, it did not prevent L3 migration. The most probable hypothesis would be that ABZ did not impede larval movement.

The results for PYR showed a high EC50 for the cyathostomin populations. In all tests, the $\mathrm{R}^{2}$ was higher than 0.90 . The results showed good applicability of the test for this drug due to its mode of action. One possible hypothesis to explain the reported results is the nicotinic action on the neuromuscular junction causing spastic paralysis; however, further tests are necessary to establish concentration limits for resistant populations.

Matthews et al. (2012) reported that the performance of in vitro assays for anthelmintic resistance in parasites of horses require further refinement, and several factors need to be taken into account when conducting LMT before interpreting the derived data (McARTHUR et al., 2015). We also believe that before running

Table 2. Effective concentration dose of $50 \%\left(\log \mathrm{EC}_{50}\right.$ in $\left.\mathrm{nMol}\right)$ and the coefficient of determination $\left(\mathrm{R}^{2}\right)$ of the five tests for albendazole, pyrantel, ivermectin and moxidectin using the larval migration on agar test against cyathostomins of horses.

\begin{tabular}{|c|c|c|c|c|c|c|c|c|}
\hline \multirow{2}{*}{$\begin{array}{l}\text { Tested drugs } \\
\text { Repetitions }\end{array}$} & \multicolumn{2}{|c|}{ Albendazole } & \multicolumn{2}{|c|}{ Pyrantel } & \multicolumn{2}{|c|}{ Ivermectin } & \multicolumn{2}{|c|}{ Moxidectin } \\
\hline & $\mathrm{EC}_{50}$ & $\mathbf{R}^{2}$ & $\mathrm{EC}_{50}$ & $\mathbf{R}^{2}$ & $\mathrm{EC}_{50}$ & $\mathbf{R}^{2}$ & $\mathrm{EC}_{50}$ & $\mathbf{R}^{2}$ \\
\hline 1 & 0.033 & 0.97 & 0.040 & 0.95 & 0.027 & 0.98 & 0.039 & 0.95 \\
\hline 2 & 0.148 & 0.81 & 0.057 & 0.97 & 0.025 & 0.98 & 0.077 & 0.85 \\
\hline 3 & 0.087 & 0.83 & 0.038 & 0.96 & 0.055 & 0.92 & 0.049 & 0.93 \\
\hline 4 & 0.167 & 0.70 & 0.047 & 0.94 & 0.035 & 0.96 & 0.073 & 0.85 \\
\hline 5 & 0.059 & 0.90 & 0.25 & 0.98 & 0.060 & 0.90 & 0.041 & 0.95 \\
\hline Average & 0.0988 & & 0.0864 & & 0.0404 & & 0.0558 & \\
\hline
\end{tabular}


(A)
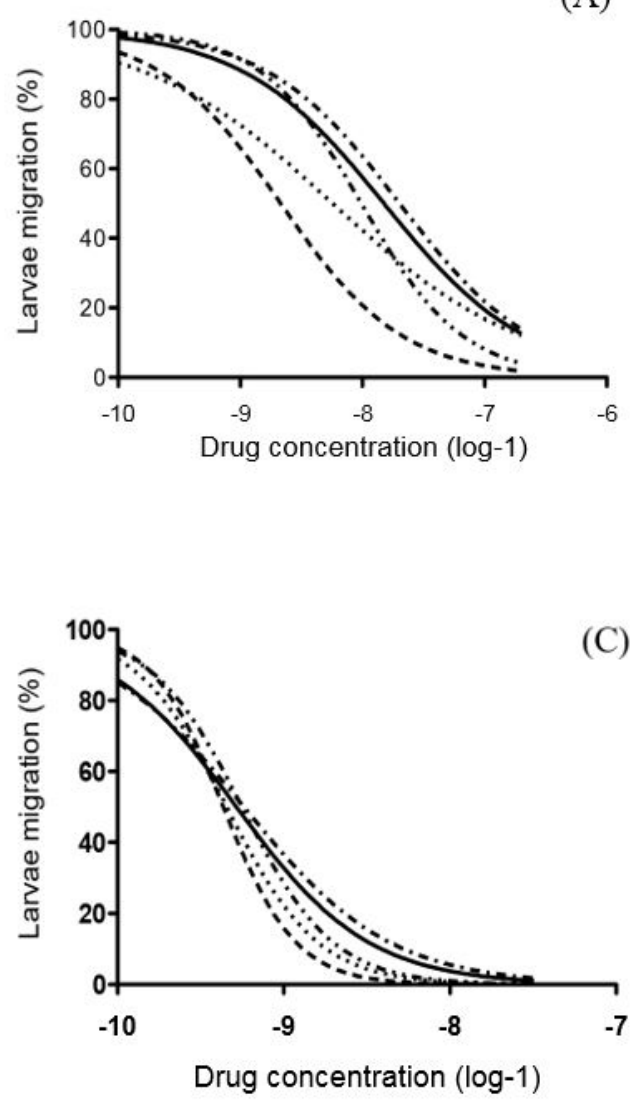

(B)
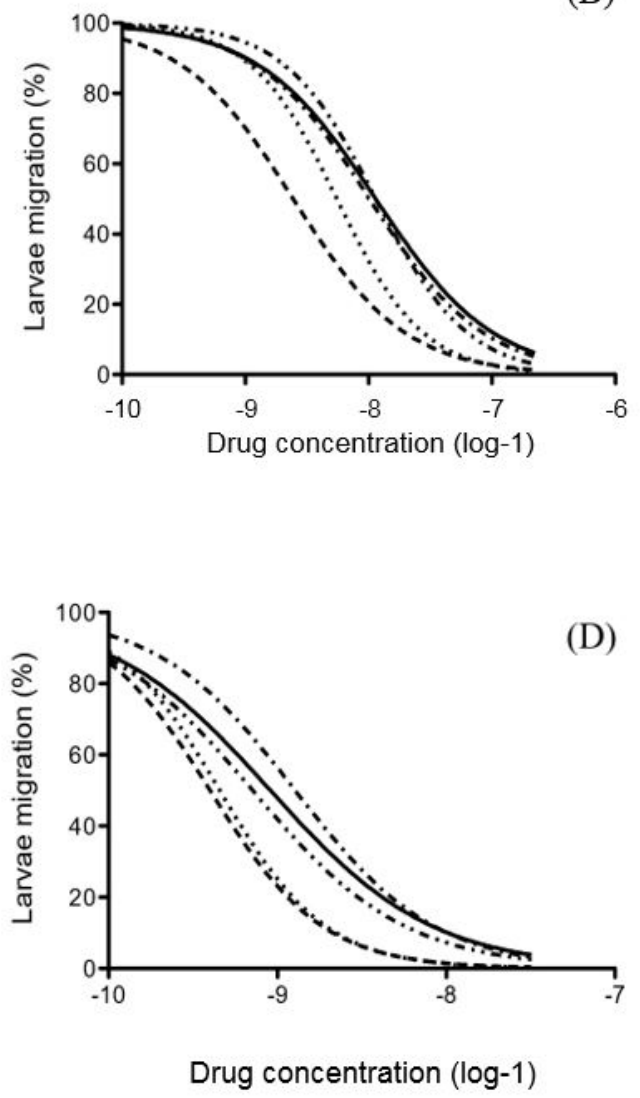

Figure 1. Effective drug concentration curves (log-1) for (A) albendazole, (B) pyrantel, (C) ivermectin and (D) moxidectin, after five independent larval migration on agar test against cyathostomins of horses.

in vitro test or comparing different efficacy methods (EHT, LM, FECRT), researchers must test the reliability of the assays, to validate the methods and calculate the level of variability. Although the reference values for each product tested in these experiments, still need further refinement (due to differences in ABZ efficacy), we have demonstrated the consistency of the LMAT method (among 5 repetitions). In the future, certified susceptible isolates could be used for screening new drug candidates, or to follow up the pattern of some anthelmintic efficacies from cyathostomin field populations.

\section{References}

Canever RJ, Braga PC, Boeckh A, Grycajuck M, Bier D, Molento MB. Lack of Cyathostomin sp. reduction after anthelmintic treatment in horses in Brazil. Vet Parasitol 2013; 194(1): 35-39. PMid:23318166. http://dx.doi.org/10.1016/j.vetpar.2012.12.020.

Craven J, Bjorn H, Barnes EH, Henriksen SA, Nansen P. A comparison of in vitro tests and a faecal egg count reduction test in detecting anthelmintic resistance in horse strongyles. Vet Parasitol 1999; 85(1): 49-59. PMid:10447192. http://dx.doi.org/10.1016/S0304-4017(99)00113-2.

Demeler J, Kuttler U, El-Abdellati A, Stafford K, Rydzik A, Várady $\mathrm{M}$, et al. Standardization of the larval migration inhibition test for the detection of resistance to ivermectin in gastro intestinal nematodes of ruminants. Vet Parasitol 2010; 174(1-2): 58-64. PMid:20850930. http:// dx.doi.org/10.1016/j.vetpar.2010.08.020.

Gill JH, Redwin JM, Van Wyk JA, Lacey E. Avermectin inhibition of larval development Haemonchus contortus: effects of ivermectin resistance. Int J Parasitol 1995; 25(4): 463-470. PMid:7635622. http://dx.doi. org/10.1016/0020-7519(94)00087-5.

Königová A, Várady M, Corba J. Comparison of in vitro methods and faecal egg count reduction test for the detection of benzimidazole resistance in small strongyles of horses. Vet Res Commun 2003; 27(4): 281-288. PMid:12872828. http://dx.doi.org/10.1023/A:1024079907895.

Kotze AC, Jambre LF, O'Grady J. A modified larval migration assay for detection of resistance to macrocyclic lactones in Haemonchus contortus, and drug screening with Trichostrongylidae parasites. Vet Parasitol 2006; 137(3-4): 294-305. PMid:16472922. http://dx.doi.org/10.1016/j. vetpar.2006.01.017.

Légaré D, Ouellette M. Drug resistance assays for parasitic diseases. Antimicrobial Drug Resist 2017; 2: 1409-1463. http://dx.doi.org/10.1007/9783-319-47266-9_36.

Lind EO, Uggla A, Waller P, Höglund J. Larval development assay for detection of anthelmintic resistance in cyathostomins of Swedish horses. Vet Parasitol 2005; 128(3-4): 261-269. PMid:15740863. http://dx.doi. org/10.1016/j.vetpar.2004.11.029.

Matthews JB, McArthur C, Robinson A, Jackson F. The in vitro diagnosis of anthelmintic resistance in cyathostomins. Vet Parasitol 2012; 185(1): 25-31. PMid:22100398. http://dx.doi.org/10.1016/j.vetpar.2011.10.014. 
McArthur CL, Handel IG, Robinson A, Hodgkinson JE, Bronsvoort BMC, Burden F, et al. Development of the larval migration inhibition test for comparative analysis of ivermectin sensitivity in cyathostomin population. Vet Parasitol 2015; 212(3-4): 292-298. PMid:26120037. http://dx.doi.org/10.1016/j.vetpar.2015.06.019.

Molento MB, Antunes J, Bentes RN, Coles GC. Anthelmintic resistant nematodes in Brazilian horses. Vet Rec 2008; 162(12): 384-385. PMid:18359933. http://dx.doi.org/10.1136/vr.162.12.384.

Molento MB, Prichard RK. Effect of multidrug resistance modulators on the activity of ivermectin and moxidectin against selected strains of Haemonchus contortus infective larvae. Pesqui Vet Bras 2001; 21(3): $117-$ 121. http://dx.doi.org/10.1590/S0100-736X2001000300004.

Nielsen MK, Monrad J, Olsen SN. Prescription-only anthelmintics - a questionnaire survey on strategies for surveillance and control of equine strongyles in Denmark. Vet Parasitol 2006; 135(1): 47-55. PMid:16309841. http://dx.doi.org/10.1016/j.vetpar.2005.10.020.

Oliveira AF, Costa LM Jr, Lima AS, Silva CR, Ribeiro MN, Mesquita JW, et al. Anthelmintic activity of plant extracts from Brazilian savanna. Vet Parasitol 2017; 236: 121-127. PMid:28288755. http://dx.doi. org/10.1016/j.vetpar.2017.02.005.

Peachey LE, Pinchbeck GL, Matthews JB, Burden FA, Behnke JM, Hodgkinson JE. Papaya latex supernatant has a potent effect on the free-living stages of equid cyathostomins in vitro. Vet Parasitol 2016; 228: 23-29. PMid:27692327. http://dx.doi.org/10.1016/j.vetpar.2016.07.036.
Peregrine AS, Molento MB, Kaplan RM, Nielsen MK. Anthelmintic resistance in important parasites of horses: does it really matter? Vet Parasitol 2014; 201(1-2): 1-8. PMid:24485565. http://dx.doi.org/10.1016/j. vetpar.2014.01.004.

Rothwell JT, Sangster NC. An in vitro assay utilizing parasitic larval Haemonchus contortus to detect resistance to closantel and other anthelmintics. Int J Parasitol 1993; 23(5): 573-578. PMid:8225759. http://dx.doi.org/10.1016/0020-7519(93)90162-R.

Traversa D, Von Samson-Himmelstjerna G, Demeler J, Milillo P, Schurmann S, Barnes H, et al. Anthelmintic resistance in cyathostomin populations from horse yards in Italy, United Kingdom and Germany. Parasit Vectors 2009;2(Suppl 2): S2. PMid:19778463. http://dx.doi. org/10.1186/1756-3305-2-S2-S2.

Van Doorn DC, Kooyman FN, Eysker M, Hodgkinson JE, Wagenaar JA, Ploeger HW. In vitro selection and differentiation of ivermectin resistant cyathostomin larvae. Vet Parasitol 2010; 174(3-4): 292-299. PMid:20850222. http://dx.doi.org/10.1016/j.vetpar.2010.08.021.

Várady M, Corba J. Comparison of six in vitro tests in determining benzimidazole and levamisole resistance in Haemonchus contortus and Ostertagia circumcincta in sheep. Vet Parasitol 1999; 80(3): 239-249. PMid:9950347. http://dx.doi.org/10.1016/S0304-4017(98)00211-8.

Wirtherle N, Schnieder T, von Samson-Himmelstjerna G. Prevalence of benzimidazole resistance on horse farms in Germany. Vet Rec 2004; 154(2): 39-41. PMid:14758828. http://dx.doi.org/10.1136/vr.154.2.39. 